\title{
Undercooling and demixing of copper-based alloys
}

\author{
Curiotto, S.; Pryds, Nini; Johnson, E.; Battezzati, L.
}

Publication date:

2005

Document Version

Publisher's PDF, also known as Version of record

Link back to DTU Orbit

Citation $(A P A)$ :

Curiotto, S., Pryds, N., Johnson, E., \& Battezzati, L. (2005). Undercooling and demixing of copper-based alloys. Abstract from 3rd Annual Meeting in the Copenhagen Graduate School for Nanoscience and Nanotechnology, Copenhagen, Denmark.

\section{General rights}

Copyright and moral rights for the publications made accessible in the public portal are retained by the authors and/or other copyright owners and it is a condition of accessing publications that users recognise and abide by the legal requirements associated with these rights.

- Users may download and print one copy of any publication from the public portal for the purpose of private study or research.

- You may not further distribute the material or use it for any profit-making activity or commercial gain

- You may freely distribute the URL identifying the publication in the public portal

If you believe that this document breaches copyright please contact us providing details, and we will remove access to the work immediately and investigate your claim. 


\title{
Undercooling and Demixing of Copper-based Alloys
}

\author{
S. Curiotto $^{\text {abc* }}$, N. H. Pryds ${ }^{a}$, E. Johnson ${ }^{a b}$, L. Battezzati ${ }^{c}$ \\ a Materials Research Department, AFM 228, Risø National Laboratory, Frederiksborgvej 399, DK-4000 Roskilde, \\ Denmark \\ ${ }^{\mathrm{b}}$ Niels Bohr Institute, Nanoscience Centre, University of Copenhagen, Copenhagen, Denmark \\ c Dipartimento di Chimica IFM, Centro di Eccellenza NIS, Università di Torino, Via P. Giuria 9, 10125 Torino, Italy
}

\begin{abstract}
Immiscible alloys have been subject to microgravity experiments since the beginning of materials science research under microgravity due to the fascinating prospect of producing fine dispersed materials for various applications. Containerless processing and rapid solidification offer new possibilities to investigate the properties of such systems. The aim of the work is to study a variety of physical phenomena, including wetting, phase separation and solidification. Of particular interest are the binary alloys Cu-Co and Cu-Fe, and the ternary system Cu-Fe-Co. All of them show a metastable miscibility gap in the regime of the undercooled melt. This paper discusses the progress made in the Microgravity Application Programme "CoolCop", financed by the European Space Agency.
\end{abstract}

